\title{
Optimasi Ekstrak Etanol Daun Sirih Merah (Piper Crocatum) sebagai Antibakteri terhadap Bakteri Staphylococcus Aureus
}

\author{
The Optimization of Red Betel Vine Leaf (Piper Crocatum) Ethanol Extract as Antibacterial against \\ Staphylococcus Aureus
}

\author{
Farida Juliantina Rachmawaty, ${ }^{1 *}$ Masyhananda Mahardika Akhmad, ${ }^{2}$ \\ Sheila Hikmah Pranacipta, ${ }^{2}$ Zulfa Nabila, ${ }^{2}$ Afivudien Muhammad ${ }^{2}$ \\ ${ }^{1}$ Departemen Mikrobiologi, Fakultas Kedokteran, Universitas Islam Indonesia \\ ${ }^{2}$ Fakultas Kedokteran, Universitas Islam Indonesia
}

\section{DATA NASKAH:}

Masuk: 10 Des 2017

Direviu: 15 Des 2017

Direvisi: 27 Des 2017

Diterima: 10 Jan 2018

\section{*KORESPONDENSI:} farida.juliantina@uii.ac.id atau

faridajuli@gmail.ac.id

DOI:

10.18196/mm.180109

TIPE ARTIKEL:

Penelitian

\begin{abstract}
Abstrak: Ekstrak etanol daun sirih merah (Piper crocatum) telah diketahui memiliki aktivitas antibakteri. Sesuai namanya, bagian bawah daun sirih merah (P. crocatum) berwarna merah sedangkan bagian atas berwarna hijau dengan corak keperakan, namun ternyata daun sirih merah dapat mengalami perubahan warna pada kondisi tertentu. Warna daun dapat berubah menjadi hijau semua (tidak ada warna merah dan corak keperakan). Di sisi lain aktivitas antibakteri ekstrak akan berfungsi efektif apabila pelarut yang digunakan tepat. Penelitian ini bertujuan untuk mengetahui ekstrak daun yang lebih efektif antara yang berwarna merah dan berwarna hijau. Tujuan berikutnya untuk mengetahui pelarut yang lebih efektif antara dimetil sulfoxid (DMSO) 10\%, Tween $801 \%$ dan aquades. Penelitian ini menggunakan metode dilusi serial untuk mengetahui Kadar Hambat Minimal (KHM) dan Kadar Bunuh Minimal (KBM) ekstrak etanol daun P. crocatum terhadap bakteri Staphylococcus aureus pada ekstrak daun berwarna berbeda dan pelarut yang berbeda. Konsentrasi yang digunakan yaitu $50 \% ; 25 \% ; 12,5 \% ; 6,25 \% ; 3,13 \% ; 1,56 \%$ dan $0,78 \%$. Hasil yang diperoleh KHM dan KBM daun warna merah $12,5 \%$ sedang untuk daun warna hijau $12,5 \%$ dan $50 \%$. Sedangkan untuk pelarut ekstrak, DMSO dapat lebih banyak membunuh bakteri dibanding yang lain. Dengan demikian dapat disimpulkan bahwa ekstrak etanol daun P. crocatum warna merah lebih baik dibanding yang berwarna hijau. Untuk pengujian pelarut, ekstrak dengan pelarut DMSO 10\%, lebih efektif dari pada Tween 80 1\% dan aquades.
\end{abstract}

Kata kunci: Optimasi; Sirih Merah (Piper Crocatum); Antibakteri; Staphylococcus Aureus

Abstract: Red betel vine leaf (Piper crocatum) ethanol extract has been known to have an antibacterial activity. As the name implies, the bottom of red betel vine leaf (P. crocatum) is red while the top is green with a silvery pattern, however $P$. crocatum leaves can experience color changes under certain conditions. The original color is red at the bottom and green with a silvery pattern at the top which can turn into all green (no red colour and silvery pattern). On the other hand the antibacterial activity of the extract will function effectively when the solvent is used appropriately. This study aims to determine the more effective leaf extracts between the red and green. The next goal is to find the more effective solvent between dimethyl sulfoxide (DMSO) 10\%, Tween 80 1\%, and aquades. This research uses a serial dilution method to know Minimal Inhibitor Concentration (MIC) and Minimal Bactericidal Concentration (MBC) of P. crocatum leaf ethanol extract against Staphylococcus aureus bacteria on different colored leaf extract and different solvent. The concentrations used were 
$50 \% ; 25 \% ; 12.5 \% ; 6.25 \% ; 3.13 \% ; 1.56 \%$ and $0.78 \%$. The result of $\mathrm{MIC}$ and $\mathrm{MBC}$ red leaf is equal at $12,5 \%$ and the green leaf is $12,5 \%$ E $50 \%$. While DMSO solvent extract was more effective for killing bacteria than others. The conclussion is ethanol extract of P. crocatum red leaf is better than the green one. Extract with DMSO 10\% was more effective than Tween $801 \%$ and aquades

Keywords: Optimization; Red Betel Vine (Piper Crocatum); Antibacteria; Staphylococcus Aureus

\section{PENDAHULUAN}

Sirih merah (Piper crocatum) merupakan salah satu tanaman obat potensial di Indonesia. Secara empiris $P$. crocatum diyakini dapat menyembuhkan penyakit infeksi dan noninfeksi. Beberapa tahun terakhir telah banyak dilakukan penelitian mengenai P. crocatum, di antaranya oleh Safithri dan Fahma (2008), ${ }^{1}$ yang melaporkan bahwa ekstrak air $P$. crocatum dapat menurunkan kadar gula tikus yang diinduksi menjadi diabetes. Peneliti lain Suratmo (2008), ${ }^{2}$ telah meneliti aktivitas antioksidan $P$. crocatum secara in vitro. Rachmawaty et al. (2009), ${ }^{3}$ meneliti kemampuan aktivitas antibakteri terhadap Staphylococcus aureus (S. aureus) dan Escherichia coli (E. coli). Rachmawaty et al. (2013), ${ }^{4}$ juga telah melakukan penelitian mengenai aktivitas antimikobakterium dan telah melakukan uji toksisitas akut dengan hasil ekstrak etanol daun $P$. crocatum aman dikonsumsi.

Sesuai dengan namanya pada bagian bawah daun P. crocatum berwarna merah hati dan bagian atas daun berwarna hijau dengan corak keperakan. Daun $P$. crocatum memiliki aroma yang khas, yakni menyengat dan tajam. Hasil kromatografi diketahui daun $P$. crocatum mengandung flavonoid, senyawa polifenol, tanin, alkaloid dan minyak atsiri. ${ }^{5}$ Daun $P$. crocatum juga mengandung saponin. ${ }^{2}$ Ekstrak etanol daun $P$. crocatum telah diketahui memiliki aktivitas antibakteri. ${ }^{3}$ Hal ini disebabkan adanya kandungan alkaloid, flavonoid, tanin, saponin dan minyak atsiri dalam $P$. crocatum yang diperkirakan berperan sebagai antibakteri. Aktivitas senyawasenyawa tersebut dengan mengganggu atau merusak membran sel atau dinding sel bakteri. Senyawa tersebut diduga banyak berada di bagian daun yang berwarna merah, ${ }^{5}$ namun pada kondisi tertentu daun $P$. crocatum dapat mengalami perubahan warna. Daun yang semula bagian bawahnya berwarna merah dapat berubah menjadi berwarna hijau semua dan corak keperakannya hilang. Penelitian sebelumnya juga menunjukkan tingkat kelarutan yang berbeda pada penggunaan pelarut yang berbeda. ${ }^{2}$ Untuk itu perlu dilakukan penelitian untuk mengetahui kondisi ekstrak terbaik yang dapat berfungsi optimal. Penelitian ini bertujuan untuk mengetahui efektivitas antibakteri daun $P$. crocatum yang berdaun merah dan yang berdaun hijau terhadap bakteri S. aureus. Tujuan berikutnya adalah untuk mengetahui pelarut terbaik antara dimetil sulfoxid (DMSO) 10\%, Tween 80 1\% dan aquades pada ekstrak etanol daun $P$. crocatum.

\section{BAHAN DAN CARA}

Desain penelitian ini merupakan penelitian eksperimental laboratorium. P. crocatum diperoleh dari tanaman toga di wilayah Sleman. Daun diambil

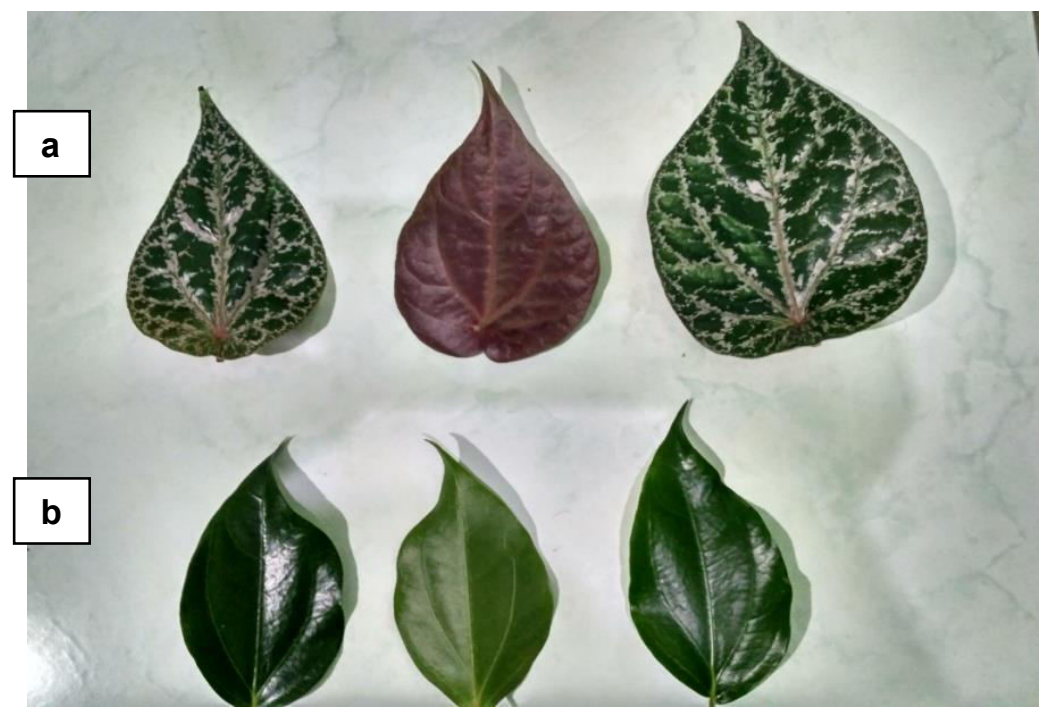

Gambar 1. a) Daun P. crocatum yang Masih Sesuai Aslinya, Bagian Bawah Daun Berwarna Merah (Tengah) Daun Bagian Atas Berwarna Hijau Dengan Corak Keperakan, b) Daun P. crocatum Yang Sudah Berubah Menjadi Berwarna Hijau Semua 
dari daun yang sudah cukup tua minimal berusia 1 bulan dari tanaman yang sudah berusia minimal 4 bulan. Warna daun akan terlihat hijau tua dengan warna merah hati yang cerah. Pada daun yang kurang dari 1 bulan warna daun tampak hijau muda. Pada daun yang sudah terlalu tua, warna merah hatinya memudar. Daun yang diperoleh disortir, daun yang tidak memenuhi syarat dibuang. Pembuatan ekstrak dilakukan dengan metode maserasi, pada setiap percobaan dibutuhkan 2 gram ekstrak. Pengujian aktivitas antbakteri dilakukan secara dilusi serial. Dengan metode ini dapat diketahui Kadar Hambat Minimal (KHM) dan Kadar Bunuh Minimal (KBM) ekstrak etanol daun $P$. crocatum yang berwarna merah dan dengan daun yang berwarna hijau terhadap S. aureus standar ATCC 25923. Bakteri diperoleh dari koleksi laboratorium Mikrobiologi Fakultas Kedokteran Universitas Indonesia.

Bakteri dari perbenihan 24 jam dibuat suspensi dengan kepadatan $10^{8} \mathrm{CFU}$ kemudian diencerkan menjadi $10^{6} \mathrm{CFU}$. Fase log yang digunakan selama 4 jam. Pengujian dengan menggunakan 11 tabung, 7 tabung untuk perlakuan dan 4 tabung sebagai kontrol. Konsentrasi akhir ekstrak yang digunakan yaitu 50\%; 25\%; $12,5 \% ; 6,25 \%$; 3,13\%; $1,56 \%$ dan $0,78 \%$. Pada setiap perlakuan disertakan 4 kontrol yang terdiri atas kontrol ekstrak, kontrol media, kontrol bakteri dan kontrol antibiotik. Antibiotik yang digunakan sebagai kontrol adalah Penicilline. Inkubasi dilakukan pada suhu $37^{\circ} \mathrm{C}$ selama $18-24$ jam.
Konsentrasi terkecil pada tabung yang tetap jernih ditentukan sebagai KHM. Selanjutnya dilakukan kultur pada agar darah. Konsentrasi terkecil pada media yang sama sekali tidak terdapat perkembangbiakan bakteri dinyatakan sebagai KBM. Hasil terbaik selanjutnya diuji dengan cara yang sama namun menggunakan pelarut yang berbeda yaitu DMSO 10\%, Tween 80 1\% dan aquades. Analisis data dilakukan secara diskriptif dengan menggunakan 3 kali hasil konsisten.

\section{HASIL}

Hasil yang diperoleh, KHM ekstrak etanol dari daun $P$. crocatum yang masih berwarna merah maupun yang berwarna hijau nampak sama yaitu pada konsentrasi $12,5 \%$. Namun setelah dikultur pada agar darah, diperoleh KBM ekstrak etanol daun yang masih berwarna merah lebih baik, yaitu pada konsentrasi 12,5\%, sedangkan daun yang berwarna hijau pada konsentrasi 50\%. Pada penilaian KHM kesulitan menentukan batasnya karena warna ekstrak pada konsentrasi yang tinggi tampak coklat kehitaman yang cenderung gelap sehingga menyulitkan dalam penilaian.

Pada penilaian KBM, berdasar ada tidaknya perkembangan bakteri di media agar darah lebih mudah menentukan dan bersifat obyektif. Gambar 3. dan Gambar 4. serta Tabel 1. Menun-jukkan bahwa ekstrak daun $P$. crocatum yang berwarna merah pada konsentrasi ke satu, dua dan tiga

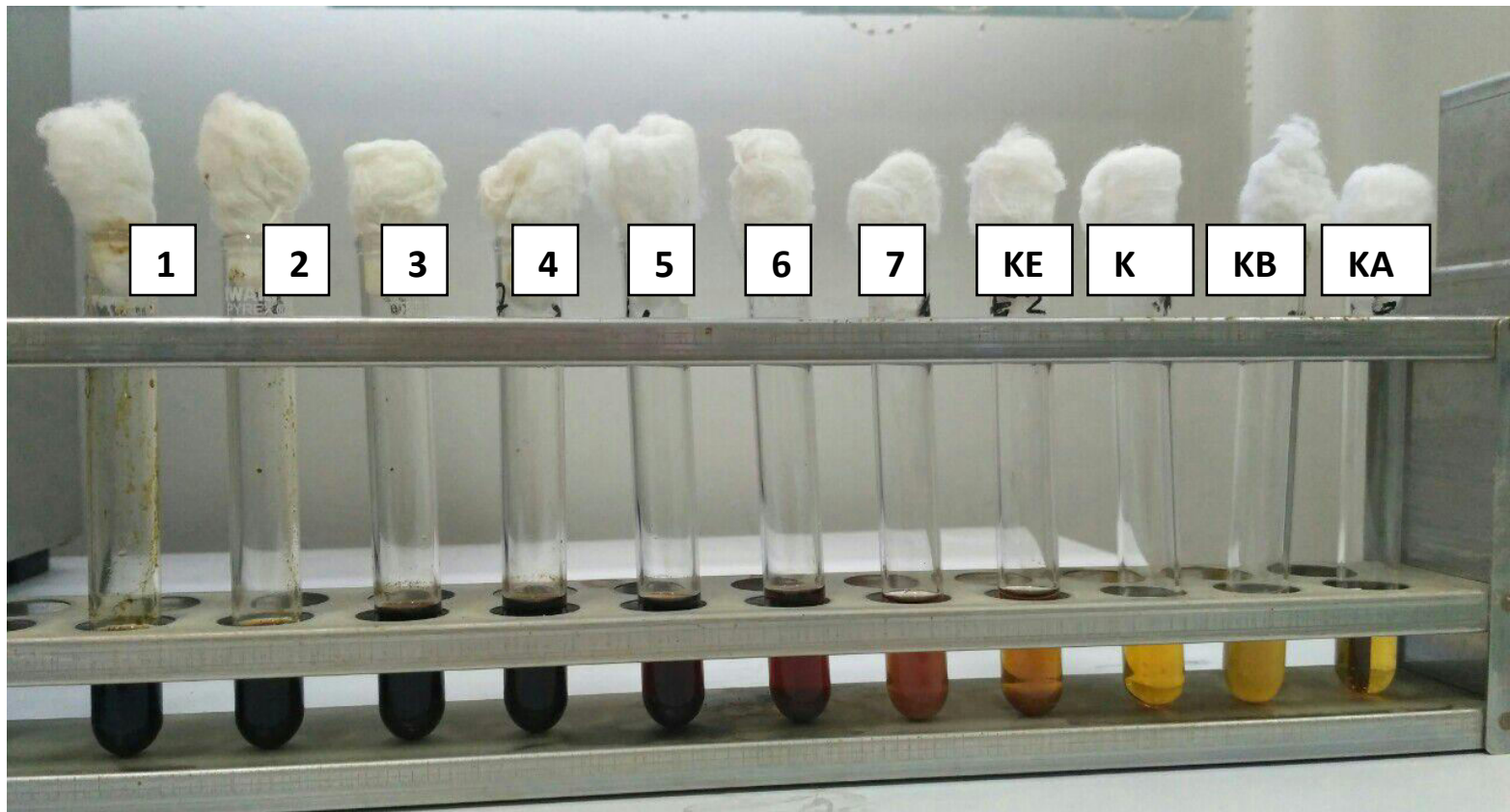

Gambar 2. Uji Dilusi Serial Ekstrak Etanol Daun P. crocatum, pada Daun yang Berwarna Merah. Konsentrasi 1:50\%. 2:25\%, 3:12,5\%, 4:6,25\%, 5:3,13\%, 6:1,56\%, 7:0,78\%. KE: Kontrol Ekstrak, KM: Kontrol Media, KB: Kontrol Bakteri dan KA: Kontrol Antibiotik 


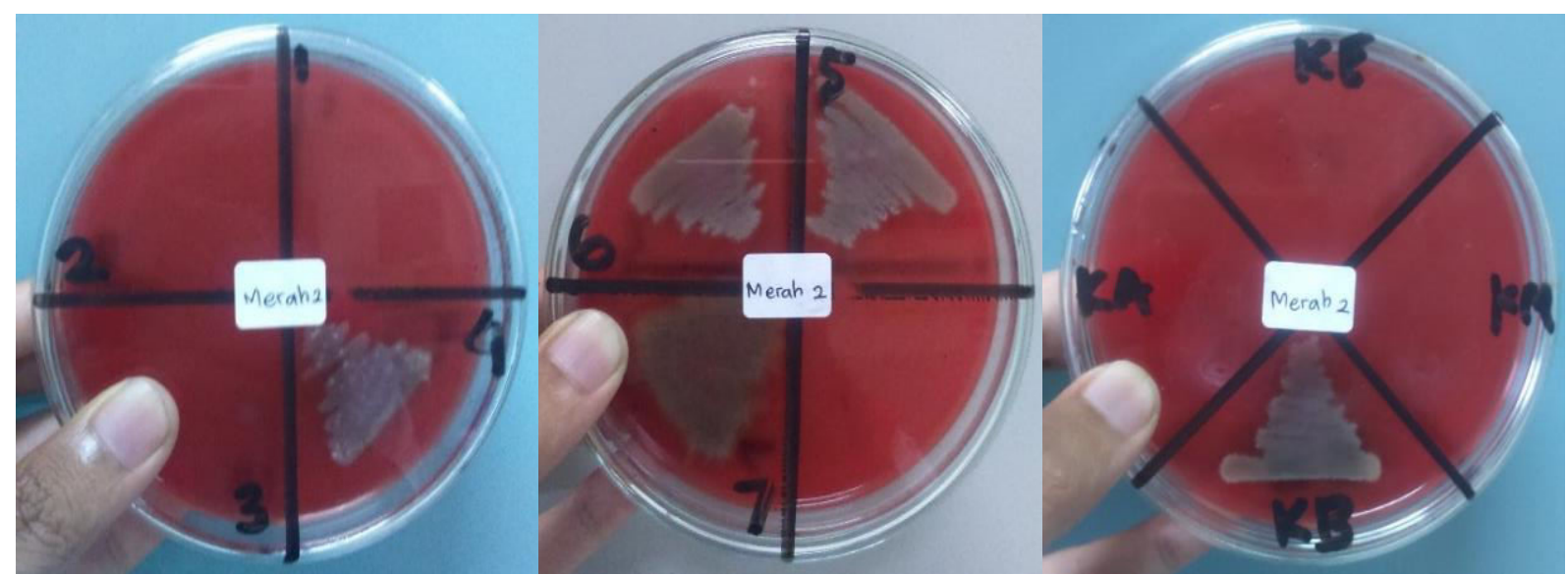

Gambar 3. Hasil Kultur pada Agar Darah, Pengujian Ekstrak Etanol Daun P. crocatum dengan Daun Warna Merah terhadap S. aureus. Konsentrasi 1:50\%. 2:25\%, 3:12,5\%, 4:6,25\%, 5:3,13\%, 6:1,56\%, 7:0,78\%. KE: Kontrol Ekstrak, KM: Kontrol Media, KB: Kontrol Bakteri dan KA: Kontrol Antibiotik

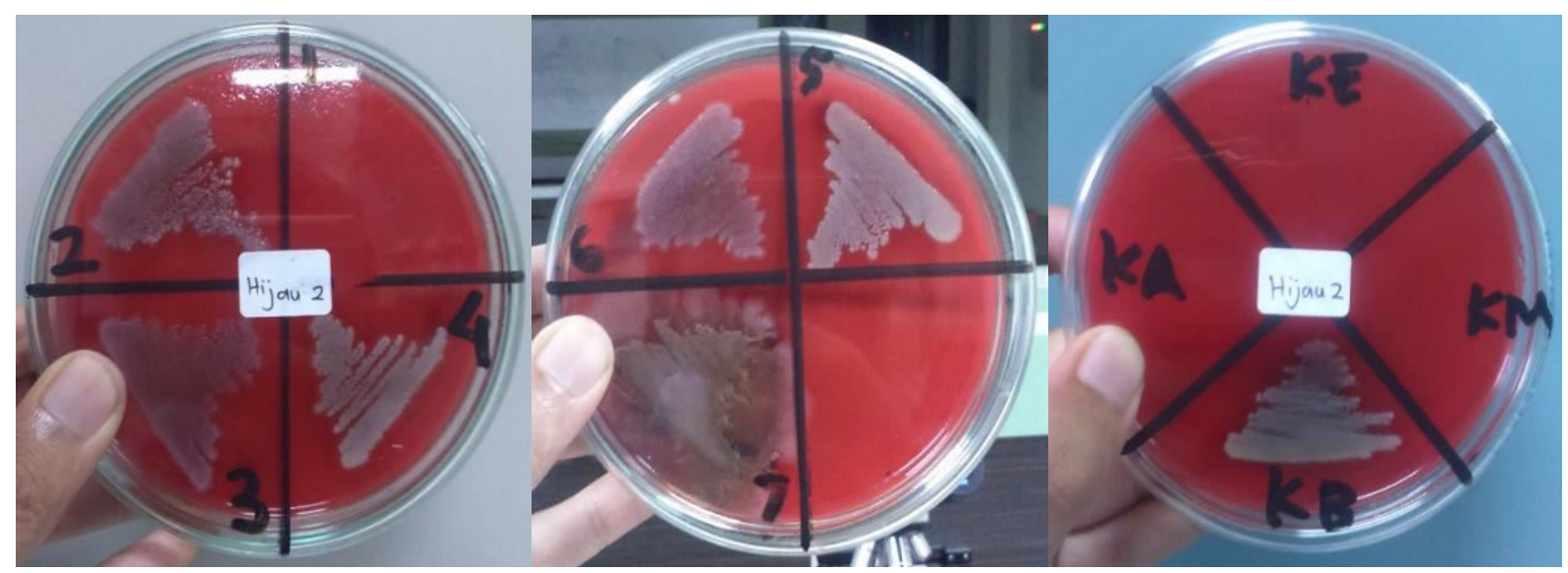

Gambar 4. Hasil Kultur pada Agar Darah, Pengujian Ekstrak Etanol Daun P. crocatum dengan Daun Warna Hijau terhadap S. aureus. Konsentrasi 1:50\%. 2:25\%, 3:12,5\%, 4:6,25\%, 5:3,13\%, 6:1,56\%, 7:0,78\%. KE: Kontrol Ekstrak, KM: Kontrol Media, KB: Kontrol Bakteri dan KA: Kontrol Antibiotik

Tabel 1. Hasil Pengujian Kadar Bunuh Minimal (KBM) Ekstrak Etanol Daun P. crocatum yang Berdaun Merah dan Berdaun Hijau

\begin{tabular}{|c|c|c|c|c|c|c|}
\hline \multirow[t]{3}{*}{ Kadar Bahan U $\underline{\mathrm{ji}}$} & \multicolumn{6}{|c|}{ Pengujian } \\
\hline & \multicolumn{3}{|c|}{ Ekstrak Daun Warna Merah } & \multicolumn{3}{|c|}{ Ekstrak Daun Warna Hijau } \\
\hline & $\mathrm{I}$ & II & III & I & II & III \\
\hline $50 \%$ & - & - & - & - & - & - \\
\hline $25 \%$ & - & - & - & + & + & - \\
\hline $12,5 \%$ & - & - & - & + & + & + \\
\hline $6,25 \%$ & + & + & + & + & + & + \\
\hline $3,13 \%$ & + & + & + & + & + & + \\
\hline $1,56 \%$ & + & + & + & + & + & + \\
\hline $0,78 \%$ & + & + & + & + & + & + \\
\hline Kontrol ekstrak & - & - & - & - & - & - \\
\hline Kontrol media & - & - & - & - & - & - \\
\hline Kontrol bakteri & + & + & + & + & + & + \\
\hline Kontrol Antibiotik & - & - & - & - & - & - \\
\hline
\end{tabular}

Keterangan: + menunjukkan ada perkembangbiakan bakteri

- menunjukkan tidak ada perkembangbiakan bakteri 


\section{mutiara medika

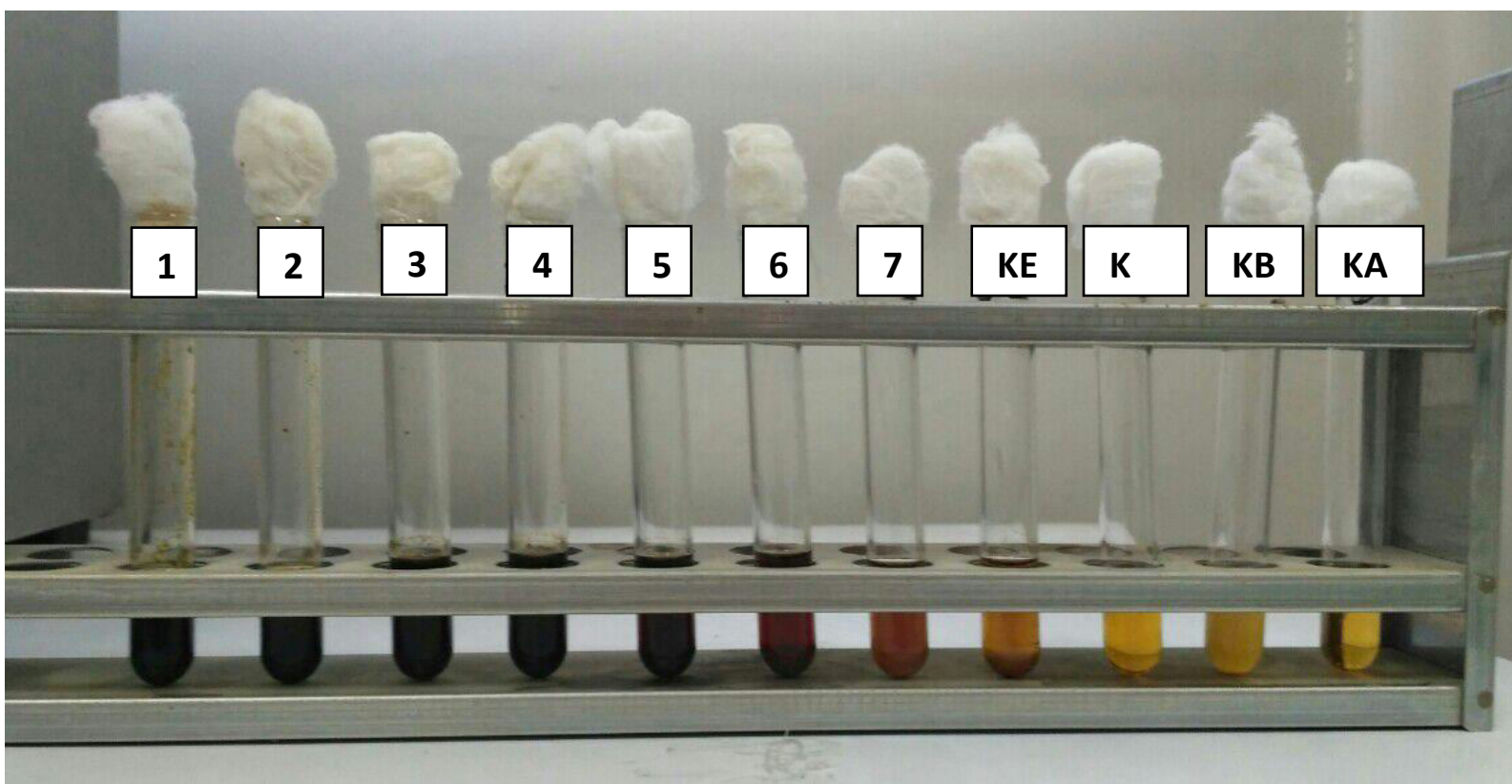

Gambar 5. Uji Dilusi Serial Ekstrak Etanol daun P. crocatum dengan Menggunakan Pelarut DMSO. Konsentrasi 1:50\%. 2:25\%, 3:12,5\%, 4:6,25\%, 5:3,13\%, 6:1,56\%, 7:0,78\%. KE: Kontrol Ekstrak, KM: Kontrol Media, KB: Kontrol Bakteri dan KA: Kontrol Antibiotik

Tabel 2. Hasil Pengujian Kadar Bunuh Minimal (KBM) Ekstrak Etanol Daun P. crocatum dengan Pelarut DMSO, Tween dan Aquades

\begin{tabular}{|c|c|c|c|c|c|c|c|c|c|}
\hline \multirow[t]{3}{*}{ Kadar Bahan Uji } & \multicolumn{9}{|c|}{ Pengujian } \\
\hline & \multicolumn{3}{|c|}{ Pelarut DMSO } & \multicolumn{3}{|c|}{ Pelarut Tween } & \multicolumn{3}{|c|}{ Pelarut Aquades } \\
\hline & I & II & III & I & II & III & I & II & III \\
\hline \multirow[t]{2}{*}{$50 \%$} & + & + & + & + & + & + & + & + & + \\
\hline & (4) & $(4)$ & $(4)$ & $(30)$ & $(5)$ & $(5)$ & (12) & $(4)$ & (2) \\
\hline \multirow[t]{2}{*}{$25 \%$} & + & + & + & + & + & + & + & + & + \\
\hline & (11) & $(30)$ & $(21)$ & $(60)$ & $(22)$ & $(22)$ & $(50)$ & (67) & (15) \\
\hline $12,5 \%$ & + & + & + & + & + & + & + & + & + \\
\hline $6,25 \%$ & + & + & + & + & + & + & + & + & + \\
\hline $3,13 \%$ & + & + & + & + & + & + & + & + & + \\
\hline $1,56 \%$ & + & + & + & + & + & + & + & + & + \\
\hline $0,78 \%$ & + & + & + & + & + & + & + & + & + \\
\hline Kontrol ekstrak & - & - & - & - & - & - & - & - & - \\
\hline Kontrol media & - & - & - & - & - & - & - & - & - \\
\hline Kontrol bakteri & + & + & + & + & + & + & + & + & + \\
\hline Kontrol Antibiotik & - & - & - & - & - & - & - & - & - \\
\hline
\end{tabular}

Keterangan: + menunjukkan ada perkembangbiakan bakteri

- menunjukkan tidak ada perkembangbiakan bakteri

Angka dalam kurung menunjukkan jumlah koloni yang tumbuh

(50\%, 25\% dan 12,5\%) tidak terdapat perkembangbiakan bakteri. Konsentrasi di bawahnya $(6,25 \%$, $3,13 \%, 1,56 \%$ dan $0,78 \%$ ) terdapat perkem-bangbiakan bakteri.

Hasil pengujian ekstrak etanol $P$. crocatum menunjukkan semua konsentrasi terdapat perkembangbiakan bakteri, namun semakin besar konsentrasi, jumlah koloni bakteri semakin sedikit. Ekstrak dengan pelarut DMSO menunjukkan jumlah koloni paling sedikit

\section{DISKUSI}

Hasil yang diperoleh, dapat dinyatakan bahwa ekstrak etanol daun $P$. crocatum yang berwarna merah lebih efektif dari pada ekstrak etanol yang diperoleh dari daun yang berwarna hijau. Hal ini diduga kandungan senyawa aktif daun P. crocatum banyak terdapat pada bagian daun yang berwarna merah. Daun P. crocatum mengandung alkaloid, flavonoid, tanin, saponin dan minyak atsiri. ${ }^{1,6}$ Pada 
daun yang sudah hilang warna merahnya dimungkinkan telah berkurang senyawa aktif yang terkandung di dalamnya. Hal ini sesuai dengan pernyataan penelitian sebelumnya bahwa tanaman P. crocatum menyukai tempat teduh, berhawa sejuk dan sinar matahari pagi hari. Apabila tumbuh di daerah panas, atau terkena paparan sinar matahari secara langsung terus-menerus, batangnya cepat mengering. Selain itu, warna merah daunnya menjadi pudar atau berubah. Padahal kemungkinan khasiatnya terletak pada senyawa kimia yang terkandung dalam warna merah daunnya. ${ }^{7}$ Dengan demikian dalam pembuatan ekstrak etanol daun $P$. crocatum perlu dilakukan penyortiran dengan baik. Penyortiran tidak hanya daun yang rusak namun juga daun yang sudah berubah warna. Hal ini diharapkan agar kualitas ekstrak dapat terjamin. Hasil nilai KHM dan KBM yang dilakukan Rachmawaty et al. (2009), ${ }^{3}$ pada bakteri yang sama menunjukkan pada konsentrasi $25 \%$. Sementara penelitian yang dilakukan Candrasari et al. (2012), ${ }^{8}$ namun dengan menggunakan bakteri ATCC yang berbeda menunjukan aktivitas antibakteri pada konsentrasi $20 \%$. Hasil penelitian ini lebih baik dari penelitian sebelumnya. Pada penelitian yang dilakukan Rachmawaty et al. (2009), ${ }^{3}$ menggunakan pelarut aquades, sedang pada penelitian ini menggunakan DMSO. Hal ini sesuai dengan penelitian selanjutnya yang menggunakan tiga pelarut yaitu DMSO, Tween 80 dan aquades.

Pada pengujian pelarut untuk ekstrak etanol, pelarut yang digunakan DMSO 10\%. Tween 80 1\% dan aquades. Hasil diperoleh ekstrak dengan pelarut DMSO lebih efektif dari pada Tween 80 dan aquades. Untuk pelarut aquades dan Tween $801 \%$ tidak menunjukkan perbedaan nyata. Hasil pengujian untuk pelarut tidak sebagus pada pengujian daun yang berwarna merah dan hijau. Hal ini dimungkinkan karena ekstrak yang digunakan bukan ekstrak baru. Dengan demikian perlu mempertimbangkan waktu pembuatan dan pelaksanaan penelitian.

Aktivitas senyawa yang terkandung di dalam $P$. crocatum yaitu alkaloid yang mempunyai aktivitas antibakteri, bahkan dapat berfungsi sebagai antibakteri pada Methicillin-resictant Staphylococcus aureus (MRSA). ${ }^{9}$ Peneliti lain menyatakan bahwa alkaloid dapat menyebabkan lisis sel atau melalui mekanisme lain dengan menghambat sintesis DNA karena dapat melakukan interkalasi. ${ }^{10}$ Flavonoid dilaporkan banyak memiliki khasiat di antaranya sebagai antibakteri, antivirus, antijamur, antiinflamasi dan beberapa aktivitas lain. ${ }^{11,12}$ Aktivitas flavonoid sebagai antibakteri telah banyak dilaporkan. ${ }^{13}$ Mekanisme beberapa golongan flavonoid di antaranya berfungsi sebagai antibakteri dengan cara meningkatkan permeabilitas membran sel. ${ }^{9}$ Menurut peneliti lain dapat menghambat sintesis DNA dan RNA atau menghambat aktivitas enzim ATPase. ${ }^{12}$ Tanin berdasar penelitian sebelumnya dilaporkan memiliki aktivitas antibakteri. ${ }^{14}$ Adapun mekanisme yang diajukan beberapa peneliti, tanin mengganggu membran sel bakteri dan membentuk senyawa kompleks dengan enzim atau substrat sehingga menghambat pertumbuhannya. ${ }^{15}$ Sementara minyak atsiri daun $P$. crocatum mengandung linalool yang dapat berfungsi sebagai antibakteri. Linalool mengandung gugus fungsi hidroksil $(-\mathrm{OH})$ yang aktif sebagai antibakteri pada umumnya. Turunan fenol berinteraksi dengan sel bakteri melalui proses adsorpsi yang melibatkan ikatan hidrogen. Pada kadar rendah terbentuk kompleks protein fenol dengan ikatan yang lemah dan segera mengalami peruraian, diikuti penetrasi fenol ke dalam sel dan menyebabkan presipitasi serta denaturasi protein. Pada kadar tinggi fenol menyebabkan koagulasi protein dan membran sel mengalami lisis. ${ }^{16}$ Minyak atsiri dapat berperan sebagai antibakteri dengan cara mengganggu proses terbentuknya membran atau dinding sel sehingga tidak terbentuk atau terbentuk tidak sempurna. ${ }^{17}$ Demikian beberapa mekanisme senyawa yang terkandung dalam ekstrak etanol daun $P$. crocatum.

\section{SIMPULAN}

Pada penelitian ini disimpulkan bahwa ekstrak etanol daun $P$. crocatum yang berdaun merah lebih efektif sebagai antibakteri terhadap bakteri $S$. aureus dibanding yang berwarna hijau. Pelarut DMSO $10 \%$ lebih efektif dibanding aquades dan Tween 80 1\%.

\section{DAFTAR PUSTAKA}

1. Safithri M, Fahma F. Potency of Piper crocatum Decoction as an Antihyperglycemia in Rat Strain Sprague dawley. Hayati J Biosci, 2008; 15 (1): 45.

2. Suratmo. Aktivitas Antioksidan dan Antikanker Ekstrak Daun Sirih Merah (P. crocatum). Tesis. Yogyakarta: Fakultas MIPA Universitas Gadjah Mada. 2008.

3. Rachmawaty FJ, Citra DA, Nirwani B, Nurmasitoh T, Bowo ET. Manfaat Sirih Merah (Piper crocatum) sebagai Agen Antibakterial terhadap Bakteri Gram Positif dan Bakteri Gram Negatif. JKKI, 2009; 1 (1): 1-10.

4. Rachmawaty FJ. Potensi Ekstrak Etanol Daun Sirih Merah (Piper crocatum) sebagai Antimikobakterium. Jurnal Ilmu Kefarmasian Indonesia, 2013; 11 (1): 60-65. 
5. Sudewo B. Basmi Penyakit dengan Sirih Merah. Surabaya: Agromedia. 2005.

6. Rachmawaty FJ. Sirih Merah dalam Kajian Ilmiah. Yogyakarta: Aswaja Pressindo. 2017.

7. Manoi F. Sirih Merah sebagai Tanaman Multi Fungsi. Warta Puslitbangbun, 2007; 13 (2): 1-2.

8. Candrasari A, Romas MA, Hasbi M, Astuti OR. Uji Daya Antimikroba Ekstrak Etanol Daun Sirih Merah (Piper crocatum Ruiz \& Pav.) terhadap Pertumbuhan Staphylococcus aureus ATCC 6538, Eschericia coli ATCC 11229 dan Candida albicans ATCC 10231 Secara in Vitro. Biomedika, 2012; 4 (1): 9-16.

9. Zuo GY, Menga FY, Haob XY, Zhanga YL, Wanga GC, Xua GL. Antibacterial Alkaloids from Chelidonium majus Linn (Papaveraceae) against Clinical Isolates of Methicillin-Resistant Staphylococcus aureus. J Pharm Pharmaceut Sci, 2009; 11 (4): 90-94.

10. Karou D, Savadogo A, Canini A, Yameogo S, Montesano C, Simpore J, et al. Antibacterial Activity of Alkaloids from Sida acuta. Afr J Biotechnol, 2005; 4 (12): 1452-1457.

11. Cushnie TP, Lamb AJ. Antimicrobial Activity of Flavonoids. Int J Antimicrob Agents, 2005; 26 (5): 343-356.

12. Shohaib T, Shafique M, Dhanya N, Divakar MC. Importance of Flavonoides in Therapeutics. H.J.D. Med, 2011; 3 (1): 1-18.

13. Quarenghi MV, Tereschuk ML, Baigori MD, Abdala LR. Antimicrobial Activity of Flowers from Anthemis cotula. Fitoterapia, 2000; 71 (6): 710-712.

14. Doss A, Mubarack M, Dhenabalan R. Antibacterial Activity of Tannin from the Leaves of Solanum trilobatum Linn. Indian J Sci Technol, 2009; 2 (2): 41-43.

15. Akiyama H, Fujii K, Yamasaki O, Oono $\mathrm{T}$, Iwatsuki T. Antibacterial Action of Several Tannins agains Staphylococcus aureus. J Antimicrob Chemother, 2001; 48 (4): 487-491.

16. Parwata IMOA, Dewi PFS. Isolasi dan Uji Aktivitas Antibakteri Minyak Atsiri dari Rimpang Lengkuas (Alpinia galanga L.). Jurnal Kimia, 2008; 2 (2): 100-104.

17. Ajizah A. Sensitivitas Salmonella typhimurium terhadap Ekstrak Daun Psidium guajava L. Bioscientiae, 2004; 1 (1): 31-38. 